JURNAL MAKSIPRENEUR, Vol. VI, No. 2, Juni 2017, hal. 36 - 55

\title{
ANALISIS PENGARUH KINERJA KEUANGAN TERHADAP RETURN TOTAL SAHAM PADA PT ELNUSA TAHUN 2009-2015
}

\author{
Khusniatul Wardah \\ Fakultas Ekonomi Universitas Proklamasi 45 Yogyakarta \\ Korespondensi penulis: khusniatulw@gmail.com
}

\begin{abstract}
This study aims to analyze the influence of fundamental factors of Current Ratio, Debt to Equity Ratio, Net Profit Margin and Total Assets Turn Over toward stock of total return on PT Elnusa, Tbk in 2009-2015. The empirical purpose is to test the signalling theory empirically through the four variables toward stock of return. Data that used in this study was obtained from secondary quantitative interim consolidated quarterly reports of companies. The multiple regression technique is used to test the effects of CR, DER, NPM, and TATO toward the stock of total return.
\end{abstract}

Keywords: current ratio (CR), debt to equity ratio (DER), net profit margin (NPM), total asset turnover (TATO).

\section{PENDAHULUAN}

Perusahaan merupakan sebuah organisasi yang didirikan guna mencapai suatu tujuan. Istilah perusahaan muncul pada saat disusunnya rancangan wetboek van koophandel atau kitab undang-undang hukum dagang yang berlaku di Belanda sejak tahun 1838. Di dalamnya termaktub penjelasan bahwa perusahaan merupakan keseluruhan perbuatan yang dilakukan secara terus menerus, tidak terputus dengan terang-terangan, dan dalam kedudukan tertentu untuk mencari laba (Silondae \& Ilyas, 2011, http://accounting-media.blogspot.co.id).

PT Elnusa merupakan sebuah perusahaan yang didirikan pada tanggal 25 Januari 1969 dengan nama awal didirikan adalah PT Electronica, Tbk. berdasarkan Akta Notaris Tan Thong Kie, S.H., No. 18 tanggal 25 Januari 1969 sebagaimana diubah melalui Akta Notaris No. 10 tanggal 13 Februari 1969 oleh notaris yang sama dan telah mendapatkan pengesahan dari Menteri Kehakiman Republik Indonesia melalui Surat Keputusan No. J.A.5/18/24 tanggal 19 Februari 1969, serta telah diumumkan di dalam Berita Negara Republik Indonesia No. 35 Tambahan No. 58 tanggal 2 Mei 1969. PT Elnusa, Tbk. merupakan sebuah perusahaan yang bergerak dalam bidang jasa, perdagangan, pertambangan, pembangunan, dan perindustrian. Lokasi perusahaan berada di Graha Elnusa Lantai 16 Jalan T.B. Simatupang Kav. 1B, Jakarta Selatan. Secara komersial, perusahaan tersebut telah beroperasi pada bulan September 1969. Pada awal kiprahnya, perseroan ini merupakan pendukung operasi PT Pertamina (Persero), terutama membantu dalam memberikan pelayanan termasuk pemeliharaan dan perbaikan, di bidang elektronik, peralatan navigasi, dan sistem radar yang digunakan oleh kapal-kapal milik Pertamina maupun kapal-kapal minyak asing yang 
memiliki perjanjian kerjasama dengan BUMN (Badan Usaha Milik Negara) di bidang Migas (Minyak dan Gas bumi).

Elnusa melakukan perampingan lini operasi dan aktivitas bisnis melalui konsolidasi internal pada tahun 1991. Hasil dari aksi ini adalah Elnusa memiliki tiga divisi yang mengelola 12 unit bisinis, yakni:

1. Divisi Eksplorasi dan Produksi

2. Divisi Teknologi Informasi

3. Divisi Patra Niaga.

Kemudian pada tahun 2001, Elnusa kembali melakukan transformasi tiga divisi tersebut menjadi dua direktorat, yakni Direktorat Layanan Hulu dan Direktorat Layanan Hilir. Elnusa melakukan inisiasi ulang proses bisnis dengan melakukan merger dan akuisisi pada tahun 2004. Hasilnya, Elnusa telah memiliki 14 afiliasi dan dua portofolio pada tahun 2006. Dengan dua fokus bisnis utama yaitu Layanan Migas Terintegrasi dan Layanan Pendukung Telematika. Tahun 2007, Elnusa melakukan restrukturisasi menjadi perusahaan pertama Indonesia yang memberikan layanan hulu migas terpadu (Integrated Upstream Indonesia and Gas Services Company). Selain itu, Elnusa memiliki empat afiliasi bisnis yang dikonsolidasikan juga ke dalam struktur korporasi guna memperkuat lini bisnis. Pada akhirnya, tahun 2008 Elnusa secara resmi terdaftar di Bursa Efek Indonesia dengan kode saham ELSA pada tanggal 6 Februari 2008 dan menggunakan nama PT Elnusa, Tbk. Saat ini, Elnusa tidak hanya melayani jasa migas. Tetapi lebih dari itu, Elnusa juga melayani jasa energi bagi klien nasional maupun internasional (sumber: http://www.elnusa.co.id, 2016).

Seiring kondisi pasang surut perekonomian di Indonesia, maka setiap perusahaan harus mengelola dan meningkatkan fungsi perusahaan dengan baik, yakni fungsi perencanaan, pengawasan, pengarahan, dan pengendalian agar tidak mengalami kemunduran. Jika fungsi manajemen tidak berjalan dengan baik, maka akan memperburuk kondisi kesehatan suatu perusahaan. Sehat atau tidaknya sebuah perusahaan dapat dilihat melalui kinerja keuangan dengan mengacu pada laporan keuangannya. Menurut Harahap (2002: 7), laporan keuangan merupakan pokok atau hasil akhir dari suatu proses akuntansi yang menjadi bahan informasi bagi para pemakainya sebagai salah satu bahan dalam proses pengambilan keputusan dan juga menggambarkan indikator kesuksesan suatu perusahaan dalam mencapai tujuannya. Laporan keuangan biasanya dipakai oleh para investor, calon investor, kreditor, pemasok, pelanggan, dan karyawan, bahkan masyarakat umum. Para pemakai laporan keuangan memiliki tujuan yang berbeda-beda sesuai dengan kapasitasnya. Jika seseorang sebagai investor, maka mereka berkepentingan terhadap risiko dan hasil dari investasi yang dilakukan. Di dalam laporan keuangan terdapat informasi fundamental yang menyangkut kondisi keuangan suatu perusahaan, maka informasi dalam laporan keuangan dapat dijadikan acuan dalam pengambilan keputusan investasi mengingat dari hasil laporan tersebut, maka apa yang akan terjadi terhadap perusahaan di masa yang akan datang dapat diproyeksikan. Hal ini dapat dilakukan dengan cara menganalisis laporan keuangannya yang dapat dilakukan dengan berbagai analisis rasio keuangan.

Bagi investor, menanamkan investasi pada suatu perusahaan maupun sekuritas adalah upaya memperoleh return (tingkat pengembalian) sesuai dengan risiko yang ditanggung pada perusahaan tersebut. Tingkat return menjadi faktor utama karena return merupakan hasil yang diperoleh dari suatu investasi (Jogiyanto, 2003: 109). Dalam menanamkan modalnya, seorang investor tentu memiliki tujuan, yaitu mengharapkan investasi jangka panjang untuk meningkatkan pendapatan total, bukan 
investasi dalam jangka pendek. Dalam hal ini, pendapatan total yang diinginkan oleh seorang investor berupa capital gain dan yield. Capital gain merupakan selisih dari harga investasi masa sekarang dengan masa lampau, sedangkan yield merupakan persentase penerimaan kas periodik dari hasil investasi dalam periode waktu tertentu.

Analisis kinerja keuangan dapat dilakukan dengan perhitungan rasio maupun perhitungan lainnya, hasil dari analisis ini dapat digunakan untuk memprediksikan perolehan return bagi para investor maupun mengetahui hal-hal yang mempengaruhi tinggi rendahnya perolehan return total saham. Informasi yang diperoleh dari hasil analisis dapat digunakan sebagai pertimbangan untuk membuat sebuah keputusan apakah investor akan berinvestasi pada perusahaan tersebut atau tidak. Dari penjelasan dalam latar belakang tersebut, penelitian ini bertujuan untuk memberikan bukti empiris mengenai pengaruh kinerja keuangan terhadap tingkat pengembalian (return) pada PT Elnusa, Tbk tahun 2009-2015.

\section{TINJAUAN PUSTAKA}

\section{Signalling Theory}

Teori sinyal atau signalling theory dijadikan sebagai model untuk memprediksikan bahwa tingkat maturitas berkorelasi dengan tingkat asimetri informasi antara pihak luar dengan pihak perusahaan. Pada motivasi signalling, manajemen melakukan kebijakan akrual yang mengarah pada persistensi laba. Motivasi signalling mendorong manajemen menyajikan laporan laba yang dapat mencerminkan laba sesungguhnya (Sunarto, 2008).

Signalling theory merupakan tindakan yang diambil perusahaan guna memberikan informasi atau gambaran kepada para investor mengenai bagaimana manajemen memandang prospek perusahaan ke depan. Sinyal ini memuat informasi apa saja yang telah dilakukan manajemen guna merealisasikan keinginan pemilik. Informasi merupakan unsur yang sangat penting bagi investor dan pelaku bisnis dikarenakan informasi pada hakekatnya menyajikan keterangan, catatan, atau gambaran, baik untuk keadaan masa lalu, saat ini, maupun masa yang akan datang bagi kelangsungan hidup perusahaan (Feri, 2014: 1528). Informasi yang dipublikasikan sebagai suatu pengumuman akan memberikan sinyal bagi investor dalam mengambil keputusan investasi. Jika yang diumumkan merupakan hal yang mengandung nilai positif, maka diharapkan pasar akan bereaksi pada saat pengumuman tersebut diterima oleh pasar (Jogiyanto, 2003: 392)

Laporan tahunan merupakan salah satu informasi yang dikeluarkan oleh perusahaan dan dapat menjadi sinyal baik bagi pihak luar. Laporan tahunan yang terbuka dan transparan akan meningkatkan daya jual saham, karena seorang investor akan memerlukan banyak informasi untuk mengevaluasi risiko yang akan dihadapi pada perusahaan tersebut, sehingga investor dapat melakukan diversifikasi portofolio dan kombinasi investasi dengan preferensi risiko yang diinginkan. Marwata (2001) menyatakan bahwa return yang meningkat akan diprediksi dan memberikan sinyal tentang laba jangka pendek dan jangka panjang dan analisis yang mengungkapkan sinyal tersebut digunakan untuk memprediksi peningkatan earning jangka panjang

\section{Saham}

Saham merupakan sebuah surat berharga yang menjadi bukti kepemilikan dari suatu perusahaan. Melalui pembelian saham perusahaan, maka seorang investor berhak mendapatkan keuntungan melalui pembagian deviden. Menurut Ang (1997) saham 
adalah surat berharga sebagai bukti penyertaan atau pemilikan individu maupun institusi dalam suatu perusahaan. Menurut Jogiyanto (2003: 67) saham dapat dibedakan menjadi: a. Saham preferen

Saham preferen merupakan saham yang memiliki sifat gabungan (hybrid) antara obligasi (bond) dengan saham biasa. Dibandingkan dengan saham biasa, dalam hal likuidasi, klaim pemegang saham preferen di bawah klaim pemegang obligasi. Jika dibandingkan dengan saham biasa, maka saham preferen memiliki hak pembayaran terlebih dahulu jika terjadi likuidasi dan memiliki hak atas deviden tetap.

b. Saham biasa

Para pemilik saham biasa yang dikeluarkan oleh perusahaan, apabila dalam sebuah perusahaan hanya memiliki satu kelas saham saja akan memiliki beberapa hak di antaranya:

- hak kontrol

- hak preemptive

- hak menerima pembagian keuntungan.

c. Saham treasuri

Saham treasuri adalah saham milik perusahaan yang sudah pernah dikeluarkan dan beredar, kemudian dibeli kembali oleh perusahaan untuk tidak dipensiunkan, tetapi disimpan sebagai treasuri.

\section{Return Total Saham}

Return merupakan hasil yang diperoleh dari suatu investasi yang telah ditanamkan oleh seorang investor pada suatu perusahaan, sedangkan return total saham merupakan return keseluruhan dari suatu investasi dalam periode waktu tertentu. Ada dua jenis return saham yakni return realisasi merupakan return yang telah terjadi dan return ekspektasi adalah return yang diharapkan akan diperoleh pada waktu yang akan datang (Jogiyanto, 2003).

Return saham terdiri atas capital gain dan yield atau return total $=$ capital gain + yield. Capital gain merupakan selisih untung dan rugi dari harga suatu investasi sekarang secara relatif dengan periode yang lalu. Jika harga investasi sekarang $\left(\mathrm{P}_{\mathrm{t}}\right)$ lebih tinggi dibandingkan dengan periode yang lalu $\left(\mathrm{P}_{\mathrm{t}-1}\right)$ artinya telah terjadi keuntungan modal (capital gain) dan sebaliknya, jika harga investasi masa yang lalu lebih tinggi dibandingkan dengan harga investasi masa sekarang artinya terjadi kerugian modal (capital loss), sedangkan yield adalah persentase penerimaan kas periodik terhadap harga investasi dalam suatu periode waktu tertentu.

Konsep yang digunakan dalam penelitian ini merupakan return realisasi yang akan diukur menggunakan return total saham. Dari konsep tersebut, maka dapat dijabarkan perhitungan return total saham dengan formula sebagai berikut:

Return total $=$ capital gain $($ loss $)+$ yield

yang mana:

Capital gain $($ loss $) \quad=\frac{\mathrm{P}_{\mathrm{t}}-\mathrm{P}_{\mathrm{t}-1}}{\mathrm{P}_{\mathrm{t}-1}}$

Yield

$$
=\frac{\mathrm{Dt}}{\mathrm{P}_{\mathrm{t}-1}}
$$

Keterangan (Jogiyanto, 2013: 110): 
$\mathrm{P}_{\mathrm{t}} \quad$ : Harga saham tahun sekarang

$\mathrm{P}_{\mathrm{t}-1} \quad$ : Harga saham periode sebelumnya

Maka, return total dapat dirumuskan sebagai berikut:

Return total $=\frac{\mathrm{P}_{\mathrm{t}}-\mathrm{P}_{\mathrm{t}-1+D_{\mathrm{t}}}}{\mathrm{P}_{\mathrm{t}-1}}$

Keterangan:

Pt : Harga saham sekarang

Pt-1 : Harga saham periode sebelumnya

Dt : Dividen kas yang dibayarkan

Perhitungan return total saham menggunakan data harga saham pada penutupan setiap akhir tahun 2011-2015 yang dinyatakan dalam rupiah.

\section{Kinerja Keuangan}

Kinerja keuangan adalah suatu analisis yang dilakukan untuk melihat sejauh mana perusahaan telah melaksanakan kegiatan keuangan perusahaan menggunakan aturanaturan pelaksanaan keuangan dengan baik dan benar (Fahmi, 2011: 2). Kinerja keuangan merupakan gambaran dari kondisi keuangan perusahaan yang dapat dianalisis menggunakan perhitungan keuangan seperti rasio, sehingga dengan hasil analisis tersebut dapat diketahui kondisi keuangan sebuah perusahaan, tingkat kesehatan, dan manajemen perusahaan guna mencerminkan prestasi kerja dalam periode waktu tertentu. Untuk menganalisis kinerja keuangan tersebut dapat dihitung menggunakan berbagai alat ukur keuangan dengan menggunakan data laporan keuangan sebagai dasar untuk menentukan atau menilai kinerja keuangan perusahaan tersebut.

Dalam penelitian ini, rasio keuangan akan digunakan untuk menganalisis kinerja keuangan perusahaan. Menurut Harahab (2002: 297), rasio keuangan merupakan angka yang diperoleh dari hasil pos perbandingan laporan keuangan dengan pos lainnya yang memiliki hubungan relevan dan signifikan. Berdasarkan tekniknya, analisis rasio keuangan terbagi menjadi empat rasio, yaitu: (1) Rasio likuiditas merupakan rasio yang mengukur kecukupan sumber kas perusahaan untuk memenuhi kewajiban yang berkaitan dengan kas dalam jangka pendek; (2) Rasio aktivitas merupakan rasio yang menunjukkan seberapa cepat unsur-unsur aktiva dapat dikonservasikan menjadi penjualan atau pun kas; (3) Rasio profitabilitas menunjukkan kemampuan perusahaan dalam menghasilkan laba; dan (4) Rasio solvabilitas menunjukkan kemampuan perusahaan dalam memenuhi kewajiban jangka panjang (Mohammad Samsul, 2006: $145)$.

\section{Laporan Keuangan}

Laporan keuangan merupakan bentuk pertanggungjawaban perusahaan terhadap para investor dan masyarakat pada umumnya. Dalam hal ini, perusahaan dapat menjadi pihak yang memberikan informasi mengenai kondisi perusahaan dan juga sebagai pihak yang dapat dievaluasi berdasarkan laporan keuangan. Beberapa tujuan dan manfaat diadakannya analisis laporan keuangan adalah mengetahui posisi keuangan perusahaan yang meliputi modal, harta, kewajiban, maupun hasil usaha pada periode waktu tertentu. Mengetahui kelemahan serta kekurangan perusahaan, karena dari kelemahan dan kekurangan ini kemudian perusahaan akan mampu mengambil langkah perbaikan untuk 
meningkatkan kinerja keuangan perusahaan. Hasil dari analisis ini juga dapat menunjukkan prestasi yang telah dicapai oleh manajemen dalam pencapaian targetnya.

Ada pun laporan keuangan yang diterbitkan oleh perusahaan, menurut Kashmir (2016) terdiri atas:

- Neraca

- Laporan rugi laba

- Laporan perubahan modal

- Laporan arus kas

- Laporan catatan atas laporan keuangan.

Laporan keuangan tersebut memuat berbagai aktivitas perusahaan yang disajikan dalam bentuk angka, baik dalam bentuk rupiah maupun mata uang asing. Jika angkaangka tersebut hanya dilihat, maka tidak akan memiliki arti dan kurang berarti, maka dari itu perlu adanya sebuah perbandingan antara satu komponen dengan komponen lainnya dengan cara membandingkan angka yang ada dalam laporan keuangan, sehingga dapat diperoleh suatu informasi mengenai kinerja keuangan perusahaan tersebut dalam periode waktu tertentu. Perbandingan ini dikenal dengan nama analisis rasio keuangan.

\section{Rasio Keuangan}

Rasio keuangan adalah angka yang diperoleh dari hasil perbandingan antara satu pos dengan pos yang lainnya dalam laporan keuangan yang memiliki hubungan yang relevan dan signifikan (Harahab, 2002: 297). Menurut Kashmir (2016), rasio keuangan dapat dibagi menjadi lima yaitu: rasio likuiditas, rasio solvabilitas, rasio profitabilitas, rasio aktivitas, dan rasio bank.

a. Rasio Likuiditas

Menurut Darsono (2005: 51), rasio likuditas adalah rasio yang memiliki tujuan untuk mengetahui kemampuan perusahaan dalam memenuhi kewajiban jangka pendeknya. Rasio likuiditas dipengaruhi oleh berbagai faktor yang dikelompokkan menjadi tiga bagian yaitu: (1) investasi dalam aktiva; (2) investasi kegiatan perusahaan; dan (3) pengendalian harta lancar. Semakin banyak dana perusahaan yang digunakan untuk harta tetap, semakin sedikit sisa untuk membiayai kebutuhan jangka pendek. Ini akan berpengaruh terhadap tingkat likuiditas perusahaan, dalam hal ini likuiditas akan menurun (Wright, 1986: 132). Dalam penelitian ini, indikator yang akan digunakan sebagai alat perhitungan rasio likuiditas adalah current ratio. Current ratio merupakan rasio yang dapat digunakan untuk menggambarkan kemampuan seluruh aktiva lancar dalam menjamin kewajibannya dalam memenuhi hutang lancarnya. Menurut Riyanto (2011: 331), current ratio yaitu kemampuan untuk membayar hutang yang segera harus dipenuhi dengan aktiva lancar yang dimiliki. Rasio ini menunjukkan tingkat keamanan (margin of safety) kreditor jangka pendek atau kemampuan perusahaan membayar kewajiban jangka pendek. Pedoman yang dianggap layak adalah 2:1 atau 200\%. Formula untuk menghitung current ratio menurut Kashmir (2016: 135) adalah sebagai berikut:

$$
\text { Current ratio }=\frac{\text { Aktiva lancar (current assets) }}{\text { Utang lancar (Current Liabilities) }}
$$

\section{b. Rasio Solvabilitas}

Rasio solvabilitas merupakan kemampuan perusahaan dalam memenuhi kewajiban jangka panjangnya. Menurut Munawir (2012: 32), rasio solvabilitas menunjukkan kemampuan perusahaan untuk memenuhi kewajiban keuangannya apabila 
perusahaan tersebut dilikuidasi, baik itu kewajiban jangka pendek maupun jangka panjang.

Apabila tingkat solvabilitas dalam suatu perusahaan tinggi, maka akan menimbulkan kerugian yang besar, tetapi hal ini juga dapat mendatangkan kesempatan untuk mendapatkan keuntungan (laba) yang besar pula. Indikator yang akan digunakan dalam penelitian untuk menghitung solvabilitas perusahaan adalah Debt to Equity Ratio (DER). DER merupakan cerminan kemampuan perusahaan dalam membayarkan seluruh kewajibannya yang ditunjukkan oleh seberapa besar modal sendiri yang digunakan untuk membayar hutang. Perusahaan dengan arus kas stabil biasanya memiliki rasio yang lebih tinggi daripada risiko kas yang kurang stabil. (Kashmir, 2016: 158). Ada pun formula untuk mencari DER adalah:

$$
\text { Debt to Equity Ratio }=\frac{\text { Total hutang (Debt) }}{\text { Ekuitas (Equity) }}
$$

\section{c. Rasio Profitabilitas}

Rasio profitabilitas merupakan rasio yang digunakan untuk menilai kemampuan perusahaan dalam mencari keuntungan. Rasio ini juga memberikan ukuran tingkat efektivitas manajemen suatu perusahaan. Hal ini ditunjukkan oleh laba yang dihasilkan dari penjualan dan pendapatan investasi. Intinya adalah penggunaan rasio ini menunjukkan efisiensi perusahaan. Menurut Awatt (1998: 391), rasio profitabilitas terdiri atas:

- Gross Profit Margin (GPM)

- Net Profit Margin (NPM)

- Rate of Return On Total Asset

- Rate of Return On Total Investment

- Rate On Equity (ROE)

Pada penelitian ini, indikator yang akan digunakan untuk menghitung rasio profitabilitas menggunakan Net Profit Margin (NPM). Net Profit Margin merupakan perbandingan antara laba setelah pajak (Earning After Tax atau EAT) dengan penjualan. Rasio ini memberikan gambaran tentang laba untuk para pemegang saham sebagai persentase penjualan. Ada pun formula yang digunakan untuk menghitung NPM adalah:

$$
\mathrm{NPM}=\frac{\text { Laba Bersih }}{\text { Penjualan Bersih }}
$$

\section{d. Rasio Aktivitas}

Rasio aktivitas merupakan rasio yang digunakan untuk mengukur efektivitas perusahaan dalam menggunakkan aktiva yang dimilikinya (Kashmir, 2016: 172). Dari hasil pengukuran ini, maka perusahaan dapat mengukur kinerja karyawannya selama ini. Selain itu, perusahaan juga dapat mengetahui berapa lama suatu piutang akan tertagih dalam periode waktu tertentu. Ada pun penggunaanya adalah dengan membandingkan tingkat penjualan dengan investasi dalam aktiva untuk satu periode.

Pada penelitian ini, untuk menghitung rasio aktivitas digunakan Total Asset Turn Over (TATO) sebagai indikator. Total Assets Turnover merupakan rasio yang digunakan untuk mengukur seberapa efisien seluruh aktiva perusahaan digunakan untuk 
menunjang kegiatan penjualan (Ang, 1997). Total Asset Turn Over memiliki formula sebagai berikut:

$$
\text { TATO }=\frac{\text { Penjualan }(\text { Sales })}{\text { Total Aktiva (Tottal Assets) }}
$$

\section{Penelitian terdahulu}

a. Ratih Diyah Safitri (2015) meneliti pengaruh current ratio, debt to equity ratio, net profit margin, dan total asset turn over terhadap return total saham pada perusahaan manufaktur yang terdaftar di Bursa Efek Indonesia. Hasil penelitian menunjukkan bahwa secara parsial, CR dan NPM tidak berpengaruh secara signifikan terhadap return total saham, sedangkan DER dan TATO berpengaruh signifikan terhadap return total saham.

b. Yeye Susilowati dan Tri Turyanto (2011) meneliti pengaruh EPS, ROA, ROE, NPM dan DER terhadap return saham perusahaan manufaktur yang terdaftar di Bursa Efek Indonesia. Hasil penelitian tersebut menunjukkan bahwa secara parsial, EPS, ROA, ROE, dan NPM tidak berpengaruh terhadap return total saham, sedangkan secara parsial DER berpengaruh signifikan terhadap return total saham.

\section{Hipotesis penelitian}

Berdasarkan penjelasan tersebut $\mathrm{di}$ atas, hipotesis dalam penelitian ini dirumuskakn sebagai berikut: current ratio (CR), debt to equity ratio (DER), net profit margin (NPM), dan total asset turn over (TATO) berpengaruh terhadap return total saham."

\section{METODE PENELITIAN}

Penelitian ini menggunakan studi kasus pada PT Elnusa, Tbk tahun 2009-2015 guna mengetahui kinerja keuangan perusahaan yang dapat mempengaruhi return total saham perusahaan. Penelitian ini menggunakan metode dokumentasi, yakni metode yang digunakan melalui pengumpulan dan pencarian data mengenai hal-hal atau variabel yang berupa catatan, transkrip, buku, surat kabar, majalah, prasasti, notulen rapat, agenda, situs web, dan data keuangan dari PT Elnusa, Tbk yang telah dipublikasikan oleh Bursa Efek Indonesia melalui situs resminya http://www.idx.co.id dan melalui situs resmi perusahaan http://www.elnusa.co.id berupa laporan keuangan konsolidasi triwulanan yang dikeluarkan perusahaan setiap tiga bulan sekali.

\section{Variabel Penelitian}

Variabel penelitian merupakan segala sesuatu yang berbentuk apa saja yang ditetapkan oleh peneliti untuk dipelajari sehingga diperoleh informasi tentang hal tersebut, kemudian ditarik kesimpulannya (Sugiyono, 2010: 2). Ada pun variabel dalam penelitian ini terbagi menjadi dua yaitu:

\section{a. Variabel Independen}

Variabel bebas merupakan variabel yang mempengaruhi atau yang menjadi akibat, karena adanya variabel bebas (Sugiyono, 2012: 4). Di dalam penelitian ini, variabel bebas terdiri atas current ratio (X1), debt to equity ratio (X2), net profit margin (X3), dan total asset turn over (X4).

\section{b. Variabel Dependen}

Menurut Sugiyono (2012: 4), variabel terikat merupakan variabel yang dipengaruhi atau yang menjadi akibat karena adanya variabel bebas. Dalam 
penelitian ini, return total saham merupakan variabel terikat. Return total saham terdiri atas capital gain (loss) dan yield. Capital gain (loss) merupakan selisih untung (rugi) dari harga investasi sekarang relatif dengan harga saham periode lalu, sedangkan yield merupakan persentase penerimaan kas periodik terhadap harga investasi periode tertentu dari suatu investasi (Jogiyanto, 2003: 110).

\section{Metode Analisis Data}

\section{a. Analisis Statistik Deskriptif}

Analisis statistuk deskriptif merupakan bentuk analisis data penelitian yang digunakan untuk menguji generalisasi penelitian berdasarkan satu sample. analisis ini juga digunakan sebagai analisis untuk rasio yang berkaitan dengan CR, DER, NPM, TATO dan return total saham pada PT Elnusa Tbk. Pada umumnya, analisis statistik deskriptif ini digunakan sebagai alat untuk menghitung ukuran pemusatan berupa rata-rata hitung, mean, median dan modus. Dalam penelitian ini analisis deskriptif digunakan untuk mengetahui nilai mean, maksimum, minimum, standar deviasi dan varian.

\section{b. Uji Asumsi Klasik}

- Uji asumsi klasik merupakan jenis pengujian yang digunakan untuk menguji asumsi kelayakan model regresi yang digunakan dalam penelitian. Pengujian yang akan dilakukan menggunakan asumsi klasik ini adalah uji normalitas, multikolinearitas, dan uji heteroskedastisitas.

- Uji Normalitas

Uji normalitas merupakan uji yang dilakukan guna melihat apakah nilai residual telah terdistribusi normal atau tidak. Menurut Ghazali (2011: 160), ada dua cara untuk mengetahui dan mendeteksi nilai residual berdistribusi normal atau tidak, yaitu dengan menggunakan analisis grafik dan uji statistik.

- Uji Multikolineartias

Uji ini digunakan untuk melihat ada atau tidaknya korelasi yang tinggi antara variabel bebas pada suatu model regresi linear berganda. Menurut Ghazali (2011: 105), uji multikolinearitas digunakan untuk menguji apakah model regresi ditemukan adanya korelasi antarvariabel bebas (independen). Pada penelitian ini, untuk menguji multikolinearitas dilakukan dengan melihat nilai tolerance dan Varian Inflation Factor (VIF). Tolerance mengukur tingkat variabilitas variabel yang terpilih yang tidak dijelaskan oleh variabel independen lain. Nilai tolerance yang rendah menunjukkan tingkat VIF yang tinggi (karena VIF $=1 /$ tolerance). Ada pun kriteria pengukuran sebagai dasar pengambilan keputusan dari tolerance dan VIF adalah (Ghazali, 2011: 105):

$>$ Tolerance

- Jika nilai tolerance $>0,10$ maka tidak terjadi multikolinearitas

- Jika nilai tolerance $<0,10$ maka terjadi multikolinearitas

$>$ VIF

- Jika VIF $<10.00$ maka tidak terjadi multikolinearitas

- Jika VIF > 10.00 maka terjadi multikolinearitas.

- Uji Heteroskedastisitas

Uji heteroskedastisitas dilakukan guna mengetahui apakah ada ketidaksamaan varians residual dari satu pengamatan ke pengamatan lainnya. Penelitian ini menggunakan dua cara untuk menguji heteroskedastisitas, di antaranya adalah 
uji scatterplot dan uji glesjer. Dasar dari pengambilan keputusan uji scatterplot adalah:

> Jika ada pola tertentu seperti titik-titik atau angka yang membentuk pola tertentu yang teratur (bergelombang, melebar, kemudian menyempit) maka mengindikasikan telah terjadi heteroskedastisitas.

$>$ Jika tidak ada pola yang membetuk atau pola yang jelas, serta titik-titik menyebar di atas dan di bawah angka 0 (nol) pada sumbu Y, maka tidak terjadi heteroskedastisitas.

Dasar pengambilan keputusan uji glesjer adalah:

$>$ Tidak terjadi heteroskedastisitas, jika t-hitung $<$ t-tabel atau nilai signifikasi $>0,05$.

$>$ Terjadi heteroskedastisitas, jika t-hitung $>\mathrm{t}$-tabel atau nilai signifikasi $<$ 0,05 .

- Uji Autokorelasi

Uji autokorelasi merupakan uji yang digunakan untuk mengetahui kesalahan pengganggu pada periode $\mathrm{t}$ dengan kesalahan pada periode $\mathrm{t}-1$ (sebelumnya) dalam model regresi. Konsekuensi dari adanya autokorelasi pada model regresi adalah varian sampel tidak menggambarkan varian populasinya. Dalam penelitian ini, uji autokorelasi yang akan digunakan adalah uji run-test. Uji tersebut dilakukan untuk mengetahui apakah antarresidual terdapat korelasi yang tinggi atau tidak. Jika tidak terdapat hubungan korelasi antarresidual maka dikatakan residual adalah acak atau random. Kriteria penerimaan uji run-test sebagai berikut:

H0: Residual random

H1: Residual tidak random

Jika hasil run-test bernilai asymptotic sygnificance (2-tailed) > nilai signifikasi $(0,05)$, maka $\mathrm{H} 0$ diterima.

\section{c. Analisis Regresi Berganda}

Analisis regresi berganda digunakan untuk menunjukkan pengaruh variabel terikat (Y) dengan beberapa variabel bebas (X). Menurut Sugiyono (2012: 276), analisis regresi berganda ini memiliki formula sebagai berikut:

$$
\mathrm{Y}=\mathrm{a}+\mathrm{b}_{1} \mathrm{x}_{1}+\mathrm{b}_{2} \mathrm{x}_{2}+\ldots . .+\mathrm{b}_{3} \mathrm{x}_{3}+\mathrm{ei}
$$

Dengan keterangan sebagai berikut:

$\mathrm{Y}=$ Return total saham

$\mathrm{A}=$ Konstanta

$\mathrm{x}_{1}=$ Current ratio $(\mathrm{CR})$

$\mathrm{x}_{2}=$ Debt to Equity Ratio (DER)

$\mathrm{x}_{3}=$ Net Profit Margin (NPM)

$\mathrm{x}_{4}=$ Total Asset Turn Over (TATO)

$\mathrm{b}_{1}, \mathrm{~b}_{2}, \mathrm{~b}_{3}, \mathrm{~b}_{4}=$ Koefisien regresi

ei $=$ Eror

\section{d. Pembuktian Hipotesis}

- Uji Simultan/Uji F

Uji $\mathrm{F}$ merupakan uji yang dilakukan guna melihat pengaruh semua variabel bebas terhadap variabel terikat serta menguji apakah model regresi yang 
digunakan telah dibuat secara signifikan atau tidak. Jika hasil dari model regresi tersebut signifikan, maka model bisa digunakan untuk melakukan prediksi dan sebaliknya.

Hipotesis uji $\mathrm{F}$ dapat dirumuskan sebagai berikut:

$\mathrm{H}_{1}: \mathrm{b}_{1}, \mathrm{~b}_{2}, \mathrm{~b}_{3}, \mathrm{~b}_{4} \neq 0$

Hal ini mengartikan bahwa terdapat pengaruh yang signifikan secara bersamasama dari variabel independen $\left(\mathrm{X}_{1}\right.$ sampai $\left.\mathrm{X}_{4}\right)$ terhadap variabel dependen $(\mathrm{Y})$.

Pengambilan keputusan:

Jika probabilitas $>0,05$ maka $\mathrm{H}_{0}$ diterima

Jika probabilitas $<0,05$ maka $\mathrm{H}_{0}$ ditolak

Adapun hipotesisnya adalah:

> H0: tidak ada pengaruh signifikan dari variabel independen terhadap variabel dependen.

> Ha: terdapat pengaruh signifikan dari variabel independen terhadap variabel dependen.

- Uji Parsial/Uji t

Uji t yang biasa disebut sebagai uji parsial ini digunakan untuk menguji bagaimana pengaruh variabel bebas secara sendiri-sendiri terhadap variabel terikatnya. Ada pun hipotesisnya adalah:

$\mathrm{H}_{1}: \mathrm{b}_{1} \neq 0$

Hal ini menunjukkan bahwa terdapat pengaruh yang signifikan dari variabel independen terhadap variabel dependen (Y).

Pengambilan keputusan:

Jika probabilitas $>0,05$ maka $\mathrm{H}_{0}$ diterima

Jika probabilitas $<0,05$ maka $\mathrm{H}_{0}$ ditolak

Hipotesisnya:

$>\mathrm{H}_{0}$ : tidak ada pengaruh signifikan dari variabel independen secara parsial terhadap variabel dependen.

$>\mathrm{H}_{1}$ : ada pengaruh signifikan dari variabel independen secara parsial terhadap variabel dependen.

- Koefisien Determinasi $\left(\mathrm{R}^{2}\right)$

Menurut Ghozali (2011: 97), koefisien determinasi pada intinya mengukur seberapa jauh kemampuan sebuah model dalam menerangkan variasi variabel dependen. Nilai koefisien determinasi adalah antara nol sampai 1 , jika $R^{2}$ memberikan nilai yang kecil, berarti bahwa variasi dependen sangat terbatas, sedangkan jika nilainya mendekati satu, maka variabel independen telah memberikan semua informasi yang dibutuhkan untuk memprediksi variabel dependen. Kelemahan jika menggunakan determinasi adalah bias terhadap jumlah variabel independen yang dimasukkan ke dalam model. Setiap tambahan variabel independen, akan terjadi peningkatan terhadap $\mathrm{R}^{2}$ tidak peduli apakah hal tersebut dapat berpengaruh terhadap variabel dependen atau tidak. Untuk itu, banyak peneliti yang menganjurkan untuk menggunakan nilai "adjusted $\mathrm{R}^{2}$ " pada saat mengevaluasi model regresi terbaik. Berbeda dari $\mathrm{R}^{2}$, adjusted $\mathrm{R}^{2}$ dapat naik atau turun berdasarkan signifikasi variabel independen.

\section{ANALISIS DAN PEMBAHASAN}

1. Perhitungan Variabel Penelitian

- Perhitungan return total saham PT Elnusa, Tbk tahun 2009-2015 


\begin{tabular}{|c|c|c|c|c|}
\hline TAHUN & KUARTAL & $\begin{array}{l}\text { HARGA } \\
\text { SAHAM }\end{array}$ & $\begin{array}{l}\text { DEVIDEN } \\
\text { KAS }\end{array}$ & $\begin{array}{c}\text { RETURN } \\
\text { TOTAL } \\
\text { SAHAM }\end{array}$ \\
\hline 2008 & $\mathrm{Q} 4$ & 117 & & \\
\hline \multirow[t]{4}{*}{2009} & Q1 & 174 & 25 & 0,540598 \\
\hline & Q2 & 340 & 25 & 0,989943 \\
\hline & Q3 & 355 & 25 & 0,0625 \\
\hline & $\mathrm{Q} 4$ & 355 & 25 & 0,017606 \\
\hline \multirow[t]{4}{*}{2010} & Q1 & 470 & 2,66 & 0,325817 \\
\hline & Q2 & 395 & 2,66 & $-0,15816$ \\
\hline & Q3 & 340 & 2,66 & $-0,13756$ \\
\hline & Q4 & 325 & 2,66 & $-0,04216$ \\
\hline \multirow[t]{4}{*}{2011} & Q1 & 295 & 0 & $-0,09231$ \\
\hline & $\mathrm{Q} 2$ & 265 & 0 & $-0,10169$ \\
\hline & Q3 & 198 & 0 & $-0,25283$ \\
\hline & $\mathrm{Q} 4$ & 230 & 0 & 0,161616 \\
\hline \multirow[t]{4}{*}{2012} & Q1 & 230 & 1,766 & 0,00192 \\
\hline & $\mathrm{Q} 2$ & 169 & 1,766 & $-0,2633$ \\
\hline & Q3 & 174 & 1,766 & 0,032198 \\
\hline & $\mathrm{Q} 4$ & 173 & 1,766 & $-0,00321$ \\
\hline \multirow[t]{4}{*}{2013} & Q1 & 190 & 16,3 & 0,121821 \\
\hline & Q2 & 260 & 16,3 & 0,389868 \\
\hline & Q3 & 280 & 16,3 & 0,092596 \\
\hline & Q4 & 330 & 16,3 & 0,193125 \\
\hline \multirow[t]{4}{*}{2014} & Q1 & 490 & 39,5 & 0,514773 \\
\hline & $\mathrm{Q} 2$ & 635 & 39,5 & 0,316071 \\
\hline & Q3 & 630 & 39,5 & 0,007677 \\
\hline & Q4 & 685 & 39,5 & 0,102976 \\
\hline \multirow[t]{4}{*}{2015} & Q1 & 530 & 10,28 & $-0,22253$ \\
\hline & Q2 & 484 & 10,28 & $-0,08194$ \\
\hline & Q3 & 334 & 10,28 & $-0,30461$ \\
\hline & Q4 & 247 & 10,28 & $-0,25278$ \\
\hline
\end{tabular}

Sumber: data sekunder yang telah diolah

- Perhitungan current ratio PT Elnusa, Tbk tahun 2009-2015

\begin{tabular}{|c|c|cc|cc|c|}
\hline TAHUN & KUARTAL & \multicolumn{2}{|c|}{ AKTIVA LANCAR } & \multicolumn{2}{c|}{ KEWAJIBAN LANCAR } & CR \\
\hline 2009 & $\mathrm{Q} 1$ & $\mathrm{Rp}$ & $1.900 .008 .000 .000,00$ & $\mathrm{Rp}$ & $1.286 .931 .000 .000,00$ & 1,47639 \\
\hline & $\mathrm{Q} 2$ & $\mathrm{Rp}$ & $2.513 .866 .000 .000,00$ & $\mathrm{Rp}$ & $1.408 .232 .000 .000,00$ & 1,78512 \\
\hline & $\mathrm{Q} 3$ & $\mathrm{Rp}$ & $2.537 .653 .000 .000,00$ & $\mathrm{Rp}$ & $1.547 .100 .000 .000,00$ & 1,64026 \\
\hline & $\mathrm{Q} 4$ & $\mathrm{Rp}$ & $2.548 .026 .000 .000,00$ & $\mathrm{Rp}$ & $1.661 .190 .000 .000,00$ & 1,53386 \\
\hline 2010 & $\mathrm{Q} 1$ & $\mathrm{Rp}$ & $2.611 .578 .000 .000,00$ & $\mathrm{Rp}$ & $1.774 .469 .000 .000,00$ & 1,47175 \\
\hline & $\mathrm{Q} 2$ & $\mathrm{Rp}$ & $2.495 .334 .000 .000,00$ & $\mathrm{Rp}$ & $1.640 .171 .000 .000,00$ & 1,52139 \\
\hline & $\mathrm{Q} 3$ & $\mathrm{Rp}$ & $2.327 .324 .000 .000,00$ & $\mathrm{Rp}$ & $1.424 .898 .000 .000,00$ & 1,63333 \\
\hline & $\mathrm{Q} 4$ & $\mathrm{Rp}$ & $2.040 .659 .000 .000,00$ & $\mathrm{Rp}$ & $1.271 .960 .000 .000,00$ & 1,60434 \\
\hline 2011 & $\mathrm{Q} 1$ & $\mathrm{Rp}$ & $2.372 .231 .000 .000,00$ & $\mathrm{Rp}$ & $1.229 .494 .000 .000,00$ & 1,92944 \\
\hline & $\mathrm{Q} 2$ & $\mathrm{Rp}$ & $2.369 .174 .000 .000,00$ & $\mathrm{Rp}$ & $1.319 .524 .000 .000,00$ & 1,79548 \\
\hline & $\mathrm{Q} 3$ & $\mathrm{Rp}$ & $2.466 .307 .000 .000,00$ & $\mathrm{Rp}$ & $1.493 .672 .000 .000,00$ & 1,65117 \\
\hline & $\mathrm{Q} 4$ & $\mathrm{Rp}$ & $2.476 .571 .000 .000,00$ & $\mathrm{Rp}$ & $1.987 .777 .000 .000,00$ & 1,24590 \\
\hline & $\mathrm{Q} 1$ & $\mathrm{Rp}$ & $2.403 .538 .000 .000,00$ & $\mathrm{Rp}$ & $1.587 .320 .000 .000,00$ & 1,51421 \\
\hline
\end{tabular}




\begin{tabular}{|c|c|c|c|c|c|c|}
\hline & Q2 & $\mathrm{Rp}$ & $2.561 .862 .000 .000,00$ & $\mathrm{Rp}$ & $1.695 .762 .000 .000,00$ & 1,51074 \\
\hline & Q3 & $\mathrm{Rp}$ & $2.489 .829 .000 .000,00$ & $\mathrm{Rp}$ & $1.613 .498 .000 .000,00$ & 1,54312 \\
\hline & Q4 & $\mathrm{Rp}$ & $2.310 .356 .000 .000,00$ & $\mathrm{Rp}$ & $1.686 .450 .000 .000,00$ & 1,36995 \\
\hline \multirow[t]{4}{*}{2013} & Q1 & $\mathrm{Rp}$ & $2.489 .545 .000 .000,00$ & $\mathrm{Rp}$ & $1.774 .909 .000 .000,00$ & 1,40263 \\
\hline & Q2 & $\mathrm{Rp}$ & $2.349 .926 .000 .000,00$ & $\mathrm{Rp}$ & $1.492 .735 .000 .000,00$ & 1,57424 \\
\hline & Q3 & $\mathrm{Rp}$ & $2.489 .677 .000 .000,00$ & $\mathrm{Rp}$ & $1.483 .628 .000 .000,00$ & 1,67810 \\
\hline & Q4 & $\mathrm{Rp}$ & $2.492 .219 .000 .000,00$ & $\mathrm{Rp}$ & $1.560 .197 .000 .000,00$ & 1,59737 \\
\hline \multirow[t]{4}{*}{2014} & Q1 & $\mathrm{Rp}$ & $2.498 .565 .000 .000,00$ & $\mathrm{Rp}$ & $1.573 .000 .000 .000,00$ & 1,58841 \\
\hline & Q2 & $\mathrm{Rp}$ & $2.458 .967 .000 .000,00$ & $\mathrm{Rp}$ & $1.590 .798 .000 .000,00$ & 1,54574 \\
\hline & Q3 & $\mathrm{Rp}$ & $2.363 .805 .000 .000,00$ & $\mathrm{Rp}$ & $1.440 .039 .000 .000,00$ & 1,64149 \\
\hline & Q4 & $\mathrm{Rp}$ & $2.236 .668 .000 .000,00$ & $\mathrm{Rp}$ & $1.378 .311 .000 .000,00$ & 1,62276 \\
\hline \multirow[t]{4}{*}{2015} & Q1 & $\mathrm{Rp}$ & $2.212 .345 .000 .000,00$ & $\mathrm{Rp}$ & $1.420 .119 .000 .000,00$ & 1,55786 \\
\hline & Q2 & $\mathrm{Rp}$ & 2.006.644.000.000,00 & $\mathrm{Rp}$ & $1.495 .552 .000 .000,00$ & 1,34174 \\
\hline & Q3 & $\mathrm{Rp}$ & $1.935 .301 .000 .000,00$ & $\mathrm{Rp}$ & $1.366 .479 .000 .000,00$ & 1,41627 \\
\hline & Q4 & $\mathrm{Rp}$ & $2.079 .319 .000 .000,00$ & $\mathrm{Rp}$ & $1.448 .585 .000 .000,00$ & 1,43541 \\
\hline
\end{tabular}

Sumber: data sekunder yang diolah

- Perhitungan debt to equity ratio PT Elnusa, Tbk tahun 2009-2015

\begin{tabular}{|c|c|c|c|c|c|}
\hline TAHUN & KUARTAL & \multicolumn{2}{|c|}{ TOTAL KEWAJIBAN } & TOTAL EQUITAS & DER \\
\hline \multirow[t]{4}{*}{2009} & Q1 & $\mathrm{Rp}$ & $1.938 .006 .000 .000,00$ & Rp 1.653.902.000.000,00 & 1,17178 \\
\hline & Q2 & $\mathrm{Rp}$ & $2.045 .721 .000 .000,00$ & Rp 2.052.754.000.000,00 & 0,99657 \\
\hline & Q3 & $\mathrm{Rp}$ & $2.116 .527 .000 .000,00$ & Rp 2.079.701.000.000,00 & 1,01771 \\
\hline & Q4 & $\mathrm{Rp}$ & $2.286 .168 .000 .000,00$ & Rp 1.909.678.000.000,00 & 1,19715 \\
\hline \multirow[t]{4}{*}{2010} & Q1 & $\mathrm{Rp}$ & $2.229 .091 .000 .000,00$ & Rp 1.959.263.000.000,00 & 1,13772 \\
\hline & Q2 & $\mathrm{Rp}$ & $2.159 .310 .000 .000,00$ & Rp 1.936.774.000.000,00 & 1,11490 \\
\hline & Q3 & $\mathrm{Rp}$ & $1.982 .322 .000 .000,00$ & Rp $1.885 .244 .000 .000,00$ & 1,05149 \\
\hline & Q4 & $\mathrm{Rp}$ & $1.728 .408 .000 .000,00$ & Rp 1.937.289.000.000,00 & 0,89218 \\
\hline \multirow[t]{4}{*}{2011} & Q1 & $\mathrm{Rp}$ & $2.040 .929 .000 .000,00$ & $\mathrm{Rp} 1.971 .189 .000 .000,00$ & 1,03538 \\
\hline & Q2 & $\mathrm{Rp}$ & $2.079 .550 .000 .000,00$ & Rp 2.018.744.000.000,00 & 1,03012 \\
\hline & Q3 & $\mathrm{Rp}$ & 2.201.933.000.000,00 & Rp 2.022.720.000.000,00 & 1,08860 \\
\hline & Q4 & $\mathrm{Rp}$ & $2.485 .125 .000 .000,00$ & Rp 1.904.825.000.000,00 & 1,30465 \\
\hline \multirow[t]{4}{*}{2012} & Q1 & $\mathrm{Rp}$ & $2.330 .553 .000 .000,00$ & Rp 1.927.679.000.000,00 & 1,20899 \\
\hline & Q2 & $\mathrm{Rp}$ & $2.385 .035 .000 .000,00$ & Rp 1.965.177.000.000,00 & 1,21365 \\
\hline & Q3 & $\mathrm{Rp}$ & $2.273 .379 .000 .000,00$ & Rp 1.990.435.000.000,00 & 1,14215 \\
\hline & Q4 & $\mathrm{Rp}$ & $2.252 .312 .000 .000,00$ & Rp 2.042.425.000.000,00 & 1,10276 \\
\hline \multirow[t]{4}{*}{2013} & Q1 & $\mathrm{Rp}$ & $2.259 .599 .000 .000,00$ & $\mathrm{Rp} 2.076 .421 .000 .000,00$ & 1,08822 \\
\hline & Q2 & $\mathrm{Rp}$ & $2.050 .013 .000 .000,00$ & Rp 2.128.884.000.000,00 & 0,96295 \\
\hline & Q3 & $\mathrm{Rp}$ & $2.071 .555 .000 .000,00$ & Rp 2.165.229.000.000,00 & 0,95674 \\
\hline & Q4 & $\mathrm{Rp}$ & $2.085 .850 .000 .000,00$ & Rp 2.285.114.000.000,00 & 0,91280 \\
\hline \multirow[t]{3}{*}{2014} & Q1 & $\mathrm{Rp}$ & $1.931 .018 .000 .000,00$ & Rp 2.337.427.000.000,00 & 0,82613 \\
\hline & Q2 & $\mathrm{Rp}$ & $1.797 .351 .000 .000,00$ & Rp 2.343.404.000.000,00 & 0,76698 \\
\hline & Q3 & $\mathrm{Rp}$ & $1.685 .387 .000 .000,00$ & Rp 2.454.984.000.000,00 & 0,68652 \\
\hline
\end{tabular}




\begin{tabular}{|l|l|ll|r|r|}
\hline & Q4 & $\mathrm{Rp}$ & $1.662 .708 .000 .000,00$ & $\mathrm{Rp} 2.549 .456 .000 .000,00$ & 0,65218 \\
\hline 2015 & $\mathrm{Q} 1$ & $\mathrm{Rp}$ & $1.720 .708 .000 .000,00$ & $\mathrm{Rp} 2.647 .419 .000 .000,00$ & 0,64996 \\
\hline & $\mathrm{Q} 2$ & $\mathrm{Rp}$ & $1.920 .992 .000 .000,00$ & $\mathrm{Rp} 2.427 .835 .000 .000,00$ & 0,79124 \\
\hline & $\mathrm{Q} 3$ & $\mathrm{Rp}$ & $1.785 .414 .000 .000,00$ & $\mathrm{Rp} 2.522 .812 .000 .000,00$ & 0,70771 \\
\hline & $\mathrm{Q} 4$ & $\mathrm{Rp}$ & $1.772 .708 .000 .000,00$ & $\mathrm{Rp} 2.635 .186 .000 .000,00$ & 0,67271 \\
\hline
\end{tabular}

Sumber: data sekunder yang diolah

- Perhitungan net profit margin PT Elnusa, Tbk tahun 2009-2015

\begin{tabular}{|c|c|c|c|c|c|}
\hline TAHUN & KWARTAL & \multicolumn{2}{|c|}{ LABA BERSIH } & PENJUALAN BERSIH & NPM \\
\hline \multirow[t]{4}{*}{2009} & Q1 & $\mathrm{Rp}$ & $40.098 .000 .000,00$ & Rp $\quad 698.171 .000 .000,00$ & 0,05743 \\
\hline & Q2 & $\mathrm{Rp}$ & $465.597 .000 .000,00$ & Rp 1.614.623.000.000,00 & 0,28836 \\
\hline & Q3 & $\mathrm{Rp}$ & $492.544 .000 .000,00$ & Rp 2.489.208.000.000,00 & 0,19787 \\
\hline & Q4 & $\mathrm{Rp}$ & 466.233.000.000,00 & Rp 3.662.331.000.000,00 & 0,12730 \\
\hline \multirow[t]{4}{*}{2010} & Q1 & $\mathrm{Rp}$ & 49.927.000.000,00 & Rp 1.147.270.000.000,00 & 0,04352 \\
\hline & Q2 & $\mathrm{Rp}$ & $27.096 .000 .000,00$ & Rp 2.267.428.000.000,00 & 0,01195 \\
\hline & Q3 & $\mathrm{Rp}$ & $11.560 .000 .000,00$ & Rp 3.190.003.000.000,00 & 0,00362 \\
\hline & Q4 & $\mathrm{Rp}$ & $63.906 .000 .000,00$ & Rp 4.210.786.000.000,00 & 0,01518 \\
\hline \multirow[t]{4}{*}{2011} & Q1 & $\mathrm{Rp}$ & $21.031 .000 .000,00$ & Rp 1.042.514.000.000,00 & 0,02017 \\
\hline & Q2 & $\mathrm{Rp}$ & $47.578 .000 .000,00$ & Rp 2.152.768.000.000,00 & 0,02210 \\
\hline & Q3 & $\mathrm{Rp}$ & $49.042 .000 .000,00$ & Rp 3.415.446.000.000,00 & 0,01436 \\
\hline & Q4 & $\mathrm{Rp}$ & $(30.115 .000 .000,00)$ & Rp 4.716.771.000.000,00 & $-0,00638$ \\
\hline \multirow[t]{4}{*}{2012} & Q1 & $\mathrm{Rp}$ & 15.924.000.000,00 & Rp 1.084.729.000.000,00 & 0,01468 \\
\hline & Q2 & $\mathrm{Rp}$ & $51.351 .000 .000,00$ & Rp 2.288.643.000.000,00 & 0,02244 \\
\hline & Q3 & $\mathrm{Rp}$ & $83.874 .000 .000,00$ & Rp 3.481.458.000.000,00 & 0,02409 \\
\hline & Q4 & $\mathrm{Rp}$ & $135.597 .000 .000,00$ & Rp 4.777.083.000.000,00 & 0,02838 \\
\hline \multirow[t]{4}{*}{2013} & Q1 & $\mathrm{Rp}$ & $36.456 .000 .000,00$ & Rp 1.046.470.000.000,00 & 0,03484 \\
\hline & Q2 & $\mathrm{Rp}$ & $86.377 .000 .000,00$ & Rp 1.974.037.000.000,00 & 0,04376 \\
\hline & Q3 & $\mathrm{Rp}$ & $122.722 .000 .000,00$ & Rp 2.920.628.000.000,00 & 0,04202 \\
\hline & Q4 & $\mathrm{Rp}$ & $242.605 .000 .000,00$ & Rp 4.111.973.000.000,00 & 0,05900 \\
\hline \multirow[t]{4}{*}{2014} & Q1 & $\mathrm{Rp}$ & $53.592 .000 .000,00$ & Rp $\quad 918.296 .000 .000,00$ & 0,05836 \\
\hline & Q2 & $\mathrm{Rp}$ & $178.597 .000 .000,00$ & Rp 2.012.559.000.000,00 & 0,08874 \\
\hline & Q3 & $\mathrm{Rp}$ & $290.177 .000 .000,00$ & Rp 3.020.953.000.000,00 & 0,09605 \\
\hline & Q4 & $\mathrm{Rp}$ & $418.092 .000 .000,00$ & Rp 4.221.172.000.000,00 & 0,09905 \\
\hline \multirow[t]{4}{*}{2015} & Q1 & $\mathrm{Rp}$ & $65.812 .000 .000,00$ & $\mathrm{Rp} \quad 924.597 .000 .000,00$ & 0,07118 \\
\hline & Q2 & $\mathrm{Rp}$ & $134.935 .000 .000,00$ & Rp 1.803.154.000.000,00 & 0,07483 \\
\hline & Q3 & $\mathrm{Rp}$ & $229.917 .000 .000,00$ & Rp 2.619.447.000.000,00 & 0,08777 \\
\hline & Q4 & $\mathrm{Rp}$ & $375.831 .000 .000,00$ & Rp 3.775.323.000.000,00 & 0,09955 \\
\hline
\end{tabular}

Sumber: data sekunder yang diolah 
- Tabel perhitungan total aset turnover PT Elnusa, Tbk tahun 2009-2015

\begin{tabular}{|c|c|c|c|c|c|}
\hline TAHUN & KUARTAL & \multicolumn{2}{|c|}{ PENJUALAN BERSIH } & TOTAL AKTIVA & TATO \\
\hline \multirow[t]{4}{*}{2009} & Q1 & $\mathrm{Rp}$ & $698.171 .000 .000,00$ & $\operatorname{Rp} 3.614 .820 .000 .000,00$ & 0,19314 \\
\hline & Q2 & $\mathrm{Rp}$ & $1.614 .623 .000 .000,00$ & $\mathrm{Rp} 4.112 .824 .000 .000,00$ & 0,39258 \\
\hline & Q3 & $\mathrm{Rp}$ & $2.489 .208 .000 .000,00$ & $\mathrm{Rp} 4.211 .037 .000 .000,00$ & 0,59112 \\
\hline & $\mathrm{Q} 4$ & $\mathrm{Rp}$ & $3.662 .331 .000 .000,00$ & Rp 4.210.421.000.000,00 & 0,86983 \\
\hline \multirow[t]{4}{*}{2010} & Q1 & $\mathrm{Rp}$ & $1.147 .270 .000 .000,00$ & $\mathrm{Rp} 4.203 .578 .000 .000,00$ & 0,27293 \\
\hline & Q2 & $\mathrm{Rp}$ & $2.267 .428 .000 .000,00$ & $\mathrm{Rp} 4.108 .672 .000 .000,00$ & 0,55186 \\
\hline & Q3 & $\mathrm{Rp}$ & $3.190 .003 .000 .000,00$ & Rp 3.881.672.000.000,00 & 0,82181 \\
\hline & Q4 & $\mathrm{Rp}$ & $4.210 .786 .000 .000,00$ & Rp 3.678.566.000.000,00 & 1,14468 \\
\hline \multirow[t]{4}{*}{2011} & Q1 & $\mathrm{Rp}$ & $1.042 .514 .000 .000,00$ & $\mathrm{Rp} 4.012 .514 .000 .000,00$ & 0,25982 \\
\hline & Q2 & $\mathrm{Rp}$ & $2.152 .768 .000 .000,00$ & $\mathrm{Rp} 4.098 .294 .000 .000,00$ & 0,52528 \\
\hline & Q3 & $\mathrm{Rp}$ & $3.415 .446 .000 .000,00$ & $\mathrm{Rp} 4.224 .653 .000 .000,00$ & 0,80846 \\
\hline & Q4 & $\mathrm{Rp}$ & $4.716 .771 .000 .000,00$ & $\mathrm{Rp} 4.389 .950 .000 .000,00$ & 1,07445 \\
\hline \multirow[t]{4}{*}{2012} & Q1 & $\mathrm{Rp}$ & $1.084 .729 .000 .000,00$ & $\mathrm{Rp} 4.258 .232 .000 .000,00$ & 0,25474 \\
\hline & Q2 & $\mathrm{Rp}$ & $2.288 .643 .000 .000,00$ & $\mathrm{Rp} 4.356 .212 .000 .000,00$ & 0,52537 \\
\hline & Q3 & $\mathrm{Rp}$ & $3.481 .458 .000 .000,00$ & Rp 4.263.814.000.000,00 & 0,81651 \\
\hline & Q4 & $\mathrm{Rp}$ & 4.777.083.000.000,00 & Rp 4.294.557.000.000,00 & 1,11236 \\
\hline \multirow[t]{4}{*}{2013} & Q1 & $\mathrm{Rp}$ & $1.046 .470 .000 .000,00$ & $\mathrm{Rp} 4.336 .020 .000 .000,00$ & 0,24134 \\
\hline & Q2 & $\mathrm{Rp}$ & $1.974 .037 .000 .000,00$ & $\mathrm{Rp} 4.178 .897 .000 .000,00$ & 0,47238 \\
\hline & Q3 & $\mathrm{Rp}$ & $2.920 .628 .000 .000,00$ & $\mathrm{Rp} 4.236 .784 .000 .000,00$ & 0,68935 \\
\hline & Q4 & $\mathrm{Rp}$ & $4.111 .973 .000 .000,00$ & $\mathrm{Rp} 4.370 .964 .000 .000,00$ & 0,94075 \\
\hline \multirow[t]{4}{*}{2014} & $\mathrm{Q} 1$ & $\mathrm{Rp}$ & $918.296 .000 .000,00$ & $\mathrm{Rp} 4.268 .445 .000 .000,00$ & 0,21514 \\
\hline & Q2 & $\mathrm{Rp}$ & $2.012 .559 .000 .000,00$ & $\mathrm{Rp} 4.140 .755 .000 .000,00$ & 0,48604 \\
\hline & Q3 & $\mathrm{Rp}$ & $3.020 .953 .000 .000,00$ & $\mathrm{Rp} 4.140 .371 .000 .000,00$ & 0,72963 \\
\hline & Q4 & $\mathrm{Rp}$ & $4.221 .172 .000 .000,00$ & $\mathrm{Rp} 4.256 .884 .000 .000,00$ & 0,99161 \\
\hline \multirow[t]{4}{*}{2015} & Q1 & $\mathrm{Rp}$ & $924.597 .000 .000,00$ & Rp 4.368.127.000.000,00 & 0,21167 \\
\hline & Q2 & $\mathrm{Rp}$ & $1.803 .154 .000 .000,00$ & $\mathrm{Rp} 4.348 .827 .000 .000,00$ & 0,41463 \\
\hline & Q3 & $\mathrm{Rp}$ & $2.619 .447 .000 .000,00$ & $\mathrm{Rp} 4.308 .226 .000 .000,00$ & 0,60801 \\
\hline & Q4 & $\mathrm{Rp}$ & $3.775 .323 .000 .000,00$ & $\mathrm{Rp} 4.407 .513 .000 .000,00$ & 0,85657 \\
\hline
\end{tabular}

Sumber: data sekunder yang diolah

\section{Analisis Data}

Sebelum melakukan pengujian terhadap hipotesis penelitian, terlebih dahulu peneliti melakukan pengujian berupa uji normalitas, uji multikolinearitas, uji heteroskedastisitas dan uji autokorelasi guna mengetahui apakah ada pelanggaran terhadap uji asumsi klasik. Dari hasil pengujian, didapatkan bahwa pada uji normalitas yang dilakukan melalui uji Kolmogorov-Smirnov didapatkan hasil bahwa nilai asymptotic significance $(0,843)>\propto(0,05)$. Hasil ini menandakan bahwa data telah terdistribusi secara normal. Begitu juga dengan hasil uji probability plot pada grafik histogram memberikan pola distribusi yang melenceng ke kanan, sedangkan pada uji multikolinearitas yang dilihat dari nilai tolerance dan VIF, semua nilai tolerance $>0,05$ dan nilai VIF $<10,00$ maka penelitian ini telah terbebas dari gejala multikolinearitas antarvariabel independen pada model regresi. Pada uji heteroskedastisitas yang 
dilakukan melalui uji scatterplot dan glesjer, hasilnya menunjukkan bahwa pada uji scatterplot menunjukkan penyebaran titik yang tidak membentuk pola tertentu dan arah penyebaran terletak di atas dan di bawah angka 0 dan sumbu Y. Uji glesjer mengindikasikan nilai signifikasi seluruh variabel lebih besar dari 0,05 maka hal ini menunjukkan bahwa model regresi ini tidak ada masalah heteroskedastisitas. Pada uji autokorelasi yang dilakukan melalui uji run-test, hasilnya menunjukkan bahwa nilai asymptotic significance $(0,178)>0,05$, maka model regresi tidak terdapat autokorelasi.

a. Statistik Diskriptif

Hasil uji statistik diskriptif pada pengolahan data melalui SPSS adalah:

Descriptive Statistics

\begin{tabular}{|l|r|r|r|r|r|}
\hline \multicolumn{1}{|c|}{ Model } & N & Minimum & Maximum & Mean & $\begin{array}{c}\text { Std. } \\
\text { Deviation }\end{array}$ \\
\hline RTS & 28 &,- 30461 &, 98994 &, 0699295 &, 29007406 \\
X1 & 28 & 1,24590 & 1,92944 & 1,5590211 &, 14271702 \\
X2 & 28 &, 64371 & 1,30465 &, 9775525 &, 19350386 \\
X3 & 28 &,- 00638 &, 34390 &, 0724189 &, 08224589 \\
X4 & 28 &, 19314 & 1,14468 &, 6098375 &, 29883801 \\
Valid N & 28 & & & & \\
(listwise) & & & & \\
\hline
\end{tabular}

Sumber: data yang diolah, SPSS 2016

Pada hasil uji statistik diskriptif tersebut, didapatkan hasil bahwa return total saham (Y) memiliki nilai rata-rata sebesar 0,0699295, nilai minimum sebesar $-0,30461$, sedangkan nilai maksimum sebesar 0.98994 .

b. Uji Hipotesis

- Uji Simultan/Uji F

Dari hasil pengujian terhadap asumsi klasik mendapatkan hasil bahwa model regresi ini telah memenuhi asumsi. Dalam penelitian ini, pengujian dilakukan menggunakan bantuan software SPSS versi 20.0. Hasil uji F adalah:

\begin{tabular}{|c|c|c|c|c|c|c|}
\hline \multicolumn{7}{|c|}{ ANOVA $^{\mathrm{a}}$} \\
\hline & Model & $\begin{array}{l}\text { Sum of } \\
\text { Squares }\end{array}$ & Df & $\begin{array}{c}\text { Mean } \\
\text { Square }\end{array}$ & $\mathbf{F}$ & Sig. \\
\hline \multirow{3}{*}{1} & Regression &, 887 & 4 &, 222 & 3,680 &, $019^{b}$ \\
\hline & Residual & 1,385 & 23 &, 060 & & \\
\hline & Total & 2,272 & 27 & & & \\
\hline
\end{tabular}

a. Dependent Variable: RTS

b. Predictors: (Constant), X4, X2, X1, X3

Sumber: Data yang telah diolah, SPSS (2016).

Berdasarkan tabel di atas terlihat bahwa F-hitung sebesar 3,680 dengan probabilitas sebesar 0,019. Hal tersebut menunjukkan bahwa p-value $0,019<$ tingkat signifikasi $(0,05)$, maka berdasarkan hasil tersebut $\mathrm{H} 0$ dapat diterima. Hasil ini 
mengindikasikan bahwa secara simultan terdapat pengaruh yang signifikan dari variabel independen $\left(\mathrm{X}_{1}\right.$ sampai $\left.\mathrm{x}_{4}\right)$ terhadap variabel dependen $(\mathrm{Y})$.

- Hasil Uji Parsial/Uji T

\begin{tabular}{|c|c|c|c|c|c|c|}
\hline \multicolumn{7}{|c|}{ Coefficients $^{\mathrm{a}}$} \\
\hline & \multirow{2}{*}{ Model } & \multicolumn{2}{|c|}{$\begin{array}{c}\text { Unstandardized } \\
\text { Coefficients }\end{array}$} & \multirow{2}{*}{$\begin{array}{c}\begin{array}{c}\text { Standardized } \\
\text { Coefficients }\end{array} \\
\text { Beta }\end{array}$} & \multirow{2}{*}{$\mathbf{t}$} & \multirow{2}{*}{ Sig. } \\
\hline & & B & $\begin{array}{l}\text { Std. } \\
\text { Error }\end{array}$ & & & \\
\hline \multirow{5}{*}{1} & (Constant) &,- 509 &, 636 & &,- 800 &, 432 \\
\hline & $\mathrm{X} 1$ & , 157 & ,339 & ,077 & ,462 & ,649 \\
\hline & $\mathrm{X} 2$ & ,273 & ,248 &, 182 & 1,102 & ,282 \\
\hline & $\mathrm{X} 3$ & 1,966 &, 601 &, 558 & 3,271 & ,003 \\
\hline & $\mathrm{X} 4$ &,- 122 &, 166 &,- 126 &,- 733 &, 471 \\
\hline
\end{tabular}

a. Dependent Variable: RTS

Sumber: Data yang diolah, SPSS (2016).

Hasil perhitungan data dengan menggunakan rumus regresi linier berganda dengan menggunakan bantuan program SPSS versi 20 diperoleh hasil sebagaimana tertera dalam table di atas.

$$
\text { Return }(\mathrm{Y})=-0,509+0,157 \mathrm{CR}+0,273 \mathrm{DER}+1,966 \mathrm{NPM}+(-0,122) \mathrm{TATO}+\mathrm{ei}
$$

Hasil persamaan regresi menunjukkan bahwa koefisien regresi variabel bebas CR, DER, dan NPM bertanda positif. Hal ini mengartikan bahwa kenaikan CR, DER, dan NPM dapat meningkatkan return saham, sedangkan TATO bertanda negatif, hal ini mengindikasikan bahwa kenaikan TATO tidak dapat meningkatkan return saham secara signifikan, sebaliknya penurunan nilai TATO akan meningkatkan return total saham.

Hasil uji parsial dijabarkan dengan hasil sebagai berikut:

\section{- Pengaruh Current Ratio terhadap Return Total Saham}

Berdasarkan hasil perhitungan di atas terlihat bahwa variabel $\mathrm{CR}$ memiliki t-hitung bertanda positif sebesar 0,462 , dengan nilai probabilitas sebesar 0,649 . Hal tersebut menunjukkan bahwa p-value $(0,649)>$ tingkat signifikasi $(0,05)$, sehingga H1 tidak dapat diterima. Artinya, CR tidak memiliki pengaruh yang signifikan terhadap return total saham. Hasil ini mengindikasikan bahwa kewajiban jangka pendek secara parsial tidak berpengaruh terhadap return total saham. Hasil ini bertentangan dengan teori yang mendasarinya bahwa CR yang semakin besar maka akan semakin besar pula kemampuan perusahaan dalam membayar kewajiban jangka pendeknya. Hal ini konsisten dengan hasil penelitian yang dilakukan oleh Safitri (2015), yaitu CR tidak memiliki pengaruh yang signifikan secara parsial terhadap return total saham.

- Pengaruh Debt to Equity Ratio terhadap Return Total Saham

Berdasarkan hasil perhitungan di atas terlihat bahwa variabel DER memiliki t-hitung bertanda positif sebesar 1,102, dan tingkat probabilitas 0,282. Hal tersebut menunjukkan bahwa p-value $(0,282)>$ tingkat signifikasi $(0,05)$, sehingga $\mathrm{H} 2$ tidak dapat diterima. Artinya, DER tidak memiliki pengaruh yang signifikan terhadap 
return total saham. Berdasarkan teori yang mendasarinya, bahwa semakin besar nilai DER pada perusahaan menunjukkan total hutang (jangka panjang dan jangka pendek) semakin besar dibandingkan dengan total equity (modal sendiri), sehingga dapat berdampak kepada semakin besarnya beban perusahaan terhadap pihak kreditur. Proporsi hutang yang terlampau besar akan menimbulkan risiko yang lebih besar pula, para pemodal akan menetapkan tingkat keuntungan yang lebih besar lagi terhadap setiap rupiah yang ditanam perusahaan tersebut (premium financial risk), sehingga nilai perusahaan cenderung turun (Yeye \& Tri, 2011: 30). Variabel DER yang berpengaruh positif tetapi tidak signifikan mengindikasikan bahwa rasio hutang tidak menyebabkan perubahan return total saham. Hasil ini tidak konsisten dengan penelitian Susilowati dan Tri (2011) serta penelitian yang dilakukan oleh Safitri (2015) yang menyatakan bahwa DER berpengaruh positif dan signifikan terhadap return total saham. Perbedaan hasil penelitian ini kemungkinan dapat disebabkan oleh perbedaan sampel yang digunakan.

\section{- Pengaruh Net Profit Margin terhadap Return Total Saham}

Hasil perhitungan pada tabel 4.13 menunjukan bahwa variabel NPM memiliki t hitung bertanda positif sebesar 3,271, dan tingkat probabilitas sebesar 0,003. Hal tersebut menunjukkan bahwa $\mathrm{p}$ value $<$ tingkat signifikansi $(0,05)$, sehingga $\mathrm{H} 3$ dapat diterima, artinya NPM memiliki pengaruh positif yang signifikan terhadap return total saham. Hal ini sesuai dengan teori yang mendasarinya bahwa NPM menunjukkan besarnya laba bersih yang diperoleh peusahaan pada setiap penjualan yang dilakukan. Semakin tinggi nilai NPM berarti akan semakin tinggi juga return yang diperoleh investor, karena NPM yang tinggi menunjukkan keuntungan yang tinggi dari setiap penjualan yang akan diterima oleh perusahaan.

\section{- Pengaruh Total Asset Turn Over terhadap Return Total Saham}

Hasil pengolahan data menunjukkan bahwa Total Assets Turn Over (TATO) memiliki t-hitung bertanda negatif sebesar $-0,733$, dan tingkat probabilitas sebesar 0,471 . Hasil tersebut menunjukkan bahwa p-value $(0,471)>$ tingkat signifikasi $(0,05)$, sehingga $\mathrm{H} 4$ tidak dapat diteima. Artinya, TATO memiliki pengaruh yang negatif dan tidak signifikan terhadap return total saham. Penelitian ini tidak konsisten dengan hasil penelitian Susilowati dan Tri (2011) dan Safitri (2015) yang menyatakan bahwa TATO berpengaruh positif signifikan terhadap return total saham, tetapi hasil penelitian ini konsisten dengan hasil penelitian Ulupui (2006) yang menyatakan bahwa TATO memiliki pengaruh negatif dan tidak signifikan. Perbedaan hasil penelitian ini dengan penelitian sebelumnya dimungkinkan terjadi akibat perbedaan sampel dan jumlah perusahaan yang diteliti mengingat dalam penelitian ini sampel yang diteliti hanya satu perusahaan saja.

Dari hasil penelitian ini, berdasarkan teori sinyal maka rasio keuangan dalam hal ini current ratio, debt to equity ratio, dan net profit margin memiliki pengaruh positif yang dapat digunakan sebagai sinyal positif untuk menilai dan meningkatkan return total saham demi memakmurkan para pemegang saham.

\section{c. Hasil Uji Koefisien Determinasi}

Dari hasil pengujian yang diolah dengan menggunakan bantuan software SPSS 20.0, koefisien determinasi yang diukur dengan adjusted $R$-squared memiliki nilai sebesar 0,284. Hasil ini menunjukkan kemampuan variabel independen (CR, DER, NPM, dan TATO) dalam menjelaskan variabel-variabel dependen (RTS) terbatas yaitu 
sebesar 28,4\%. Sisanya sebesar 71,6\% dijelaskan oleh variabel lain di luar model regresi di dalam penelitian ini.

\section{PENUTUP}

a. Kesimpulan

- Berdasarkan hasil penelitian ini, variabel NPM terbukti berpengaruh positif dan signifikan trehadap return total saham, sedangkan variabel CR, DER, dan TATO tidak berpengaruh terhadap return total saham pada PT Elnusa, Tbk tahun 20092015.

- Hasil penelitian ini juga menunjukkan bahwa variabel CR, NPM, dan DER memiliki kemampuan prediksi terhadap return total saham pada PT Elnusa, Tbk.

b. Keterbatasan penelitian

Penelitian ini memiliki beberapa keterbatasan, yakni hanya variabel NPM yang terbukti berpengaruh positif signifikan. Hal ini dapat terjadi karena keterbatasan obyek dan data penelitian mengingat dalam penelitian ini hanya mengkaji data dari satu perusahaan saja. Hal ini dimungkinkan untuk melakukan penelitian lebih lanjut dengan memperluas cakupan penelitian, seperti sektor jasa, pertambangan, industri, dan lainlain. Hasil penelitian pada PT Elnusa, Tbk juga tidak dapat digeneralisasikan kepada semua jenis perusahaan.

c. Saran

Bagi penelitian selanjutnya, untuk mendapatkan hasil yang lebih maksimal, maka dapat menambahkan faktor fundamental lain, seperti rasio pasar dan rasio aktivitas perusahaan. Selain itu, penelitian mendatang dapat memperluas cakupan dengan menghubungkan variabel makro ekonomi dan non-ekonomi, seperti kurs, ekspor-impor, dan sebagainya.

\section{DAFTAR REFERENSI}

Arikunto, S. (2010). Prosedur Penelitian. Jakarta: Rineka Cipta.

Awat, N.J. (1998). Manajemen Keuangan: Pendekatan Matematis. Jakarta: Gramedia Pustaka Utama.

Brigham, E.F. \& Houston, J.F. (2001). Manajemen Keuangan. Jakarta: Erlangga.

Darsono. (2005). Pedoman Praktis Memahami Laporan Keuangan. Yogyakarta: Andi Offset.

Diyah, S.R. (2015). Pengaruh Kinerja Keuangan Perusahaan terhadap Return Total Saham pada Perusahaan Manufaktur yang Terdaftar di Bursa Efek Indonesia. Skripsi. Semarang: Universitas Negeri Semarang.

Fahmi, I. 2011. Analisis Kinerja Keuangan, Panduan bagi Akademik, Manajer, dan Investor Untuk Menilai dan Menganalisis Bisnis dari Aspek Keuangan. Bandung: Alfabeta.

Feri, M. (2014). Pengaruh Rasio Profitabilitas terhadap Perubahan Harga Saham pada Perusahaan Sektor Properti yang Listing di Bursa Efek Indonesia Periode 20082012. Jurnal Ilmu Manajemen, Vol. 2, No.4.

Ghozali, I. (2011). Aplikasi Analisis Multivariate dengan Program IBM SPSS 19. Semarang: Badan Penerbit Universitas Diponegoro. 
Harahab, S.S. (2002). Analisa Kritis Atas Laporan Keuangan. Jakarta: PT.Raja Grafindo Persada.

Jogiyanto, H. (2003). Teori Portofolio dan Analisis Investasi. Yogyakarta: BPFE.

Kasmir. (2012). Bank dan Lembaga Keuangan Lainnya. Edisi Keenam. Jakarta: Raja Grafindo Persada.

Kasmir. (2016). Analisis Laporan Keuangan. Cetakan Kesembilan. Jakarta: Rajawali Pers.

Marwata. (2001). Hubungan antara Karakteristik Perusahaan dan Kualitas Ungkapan Sukarela dalam Laporan Tahunan Perusahaan Publik di Indonesia. Makalah dipresentasikan dalam Simposium Nasional Akuntansi IV, 2001.

Munawir. (2002). Analisa Laporan Keuangan. Yogyakarta: Liberty.

Prastowo, D. (2011). Analisis Laporan Keuangan. Edisi Ketiga. Yogyakarta: STIM YKPN.

Riyanto, B. (2001). Dasar-dasar Pembelanjaan Perusahaan. Yogyakarta: BPEE UGM.

Robert, A. (1997). Buku Pintar Pasar Modal Indonesia. Jakarta. Mediasoft Indonesia.

Samsul, M. (2006). Pasar Modal \& Manajemen Portofolio. Jakarta: Erlangga.

Senohadi, V.S. (2014). Pengaruh Nilai Buku, Economic Value Added, dan Return On Asset terhadap Return Saham. Jurnal Riset Manajemen \& Bisnis, Universitas Kristen Duta Wacana.

Silondae, A.A. \& Ilyas, W.B. (2011). Pokok-Pokok Hukum Bisnis. Jakarta: Penerbit Salemba Empat.

Singgih, S. (2000). SPSS: Mengolah Data Statistik Secara Profesional. Edisi Kedua. Jakarta: PT Elex Media Komputindo.

Sugiyono. (2010). Metode Penelitian Kuantitatif Kualitatif dan R\&D. Bandung: Alfabeta.

Susilowati, Y. \& Turyanto, T. (2011). Reaksi Sinyal Rasio Profitabilitas dan Rasio Solvabilitas terhadap Return Saham Perusahaan. Jurnal Dinamika Keuangan dan Perbankan, Vol 3, No. 1, hal 68-87.

Tika, M.P. (2006). Analisis Pengaruh Rasio Keuangan terhadap Total Return pada Perusahaan Manufaktur di Bursa Efek Jakarta. Skripsi. Semarang: Universitas Negeri Semarang.

Ulupui, I.G.K.A. (2006). Analisis Pengaruh Rasio Likuiditas, Leverage, Aktivitas dan Profitabilitas terhadap Return Saham (Studi Pada Perusahaan Makanan dan Minuman dengan Kategori Industri Barang Konsumsi di BEJ. Jurnal Akuntansi. Vol 2, No.1.

White, G.I., Ashwinpaul, C.S. \& Fried, D. (2003). The Analysis and Use of Financial Statements. USA: John Wiley \& Sons, Inc.

http://www.elnusa.co.id (2016).

$\mathrm{http} / / \mathrm{www} . i d x . c o . i d(2016)$.

http://accouunting-media.blogspot.co.id (2016). 